\section{Palaeo-seawater of Kutch region, Gujarat, India}

\author{
Tirumalesh Keesari* and Uday Kumar Sinha \\ Isotope and Radiation Application Division, \\ Bhabha Atomic Research Centre, Mumbai 400 085, India
}

Earthquakes provide an opportunity not only to unravel the hidden mysteries of nature but also facilitate calculation of the magnitude of palaeo-earthquakes by studying liquefaction features and reveal the presence of buried water bodies, etc. The $M_{w} 7.7$ Bhuj earthquake (2001) led to widespread liquefaction giving rise to sand blows, craters and lateral spreading. Near Chobari, sand and water spouts were found while some palaeo-channels and water bodies were found in Kulvida and Khadi. This study discusses the source of water to springs erupted near Lodai and demonstrates the usefulness of environmental isotopes in understanding the palaeo-salinity sources and processes. The linkage of spring water with past episodes of seawater intrusion was also briefed.

Keywords: Earthquakes, groundwater, palaeo-seawater, saline springs.

RECENT news on fossils in western India ${ }^{1-4}$ has prompted this study on saline springs which emerged during the devastating earthquake of magnitude $M_{w} 7.7$ that hit the Bhuj area and its surroundings in Kutch region, Gujarat on 26 January 2001 (ref. 5) (Figure $1 a$ ). It was the largest earthquake in this region in the last 50-60 years ${ }^{6}$. Many tectonic, geomorphologic and geohydrologic changes took place during this event generating a variety of liquefaction-related features, including lateral spreading, sand blows and water spouts ${ }^{5}$. Several springs were found spouting water which lasted for weeks to several months after the earthquake event (Figure $1 b$ ). Two such springs near Lodai village, Bhuj, were sampled immediately after the event to identify their source and recharge history using isotopic and hydrochemical techniques (Figure $1 c$ ).

The spring samples were collected at the outlet of the springs (fresh ooze), filtered using $0.45 \mu \mathrm{m}$ pore size membrane filters and stored in pre-cleaned polyethylene bottles (1 litre, Tarson-make) until further measurements. A duplicate set was collected and acidified to $\mathrm{pH} 2$ by adding ultra-pure concentrated $\mathrm{HNO}_{3}$ for cation measurements. Physical parameters were measured in situ using Corning meter (model 313) for $\mathrm{pH}$ and Orion meter (model 130) for temperature and electrical conductivity. Alkalinity was measured in the field by titrating $10 \mathrm{ml}$ of water sample with $0.02 \mathrm{~N} \mathrm{H}_{2} \mathrm{SO}_{4}$ using a mixed indicator (bromocresol green-methyl red) to mark the end-point.

\footnotetext{
*For correspondence. (e-mail: tirumal@barc.gov.in)
}

Anions (viz. $\mathrm{Cl}^{-}, \mathrm{SO}_{4}^{2-}, \mathrm{Br}^{-}, \mathrm{NO}_{3}^{-}$and $\mathrm{F}^{-}$) and cations (viz. $\mathrm{Na}^{+}, \mathrm{Ca}^{2+}, \mathrm{Mg}^{2+}, \mathrm{K}^{+}$and $\mathrm{Li}^{+}$) were analysed using ion chromatography (Dionex, DX-500) employing an electrochemical detector (ED 40). Strontium was measured by ICP-MS and boron by spectrophotometer. The accuracy of the chemical ion data was calculated using charge balance equation (eq. (1)) and the charge balance error (CBE) values of the spring water samples were within the accepted limits of $\pm 5 \%$ (ref. 7). Table 1 lists the hydrochemical data

$$
\operatorname{CBE}(\%)=\frac{\text { meq }(\text { cations })-\text { meq }(\text { anions })}{\text { meq }(\text { cations })+\text { meq }(\text { anions })} \times 100 .
$$

For stable isotope $\left({ }^{2} \mathrm{H}\right.$ and $\left.{ }^{18} \mathrm{O}\right)$ analysis, water samples were collected in $50 \mathrm{ml}$ airtight, high-density polyethylene bottles and measurements were made using duel inlet isotope-ratio mass spectrometer (Geo 20-20, Europa). The chemical and isotope measurements are carried out in Isotope Hydrology Section (IRAD), Bhabha Atomic Research Centre, Mumbai. Details of the isotope measurements are elaborated in Keesari et al. ${ }^{8}$. The results are reported in $\delta$-notation and expressed in units of parts per thousand (\%o) with respect to Vienna Standard Mean Ocean Water (VSMOW). The $\delta$-values are calculated using eq. (2) as follows ${ }^{9}$

$$
\delta(\%)=\left(\frac{R_{x}}{R_{\mathrm{S}}}-1\right) \times 1000,
$$

where $R$ denotes the ratio of heavy to light isotopes (e.g. ${ }^{2} \mathrm{H} /{ }^{1} \mathrm{H}$ or ${ }^{18} \mathrm{O} /{ }^{16} \mathrm{O}$ ), and $R_{x}$ and $R_{\mathrm{s}}$ are the ratios in the sample and standard respectively. The precision of measurement for $\delta^{2} \mathrm{H}$ is $\pm 0.5 \%$ and for $\delta^{18} \mathrm{O}$ is $\pm 0.1 \%$ ( $\left.1 \sigma\right)$. The isotope measurements were periodically crosschecked through inter-comparison exercise conducted by International Atomic Energy Agency, Vienna, Austria.

Spring-water samples were found to be hyper-saline with electrical conductivities in the order of $100,000 \mu \mathrm{S} / \mathrm{cm}$ and chemically belong to NaCl-type (Table 1). These saline springs showed very high contents of minor ions such as $\mathrm{B}, \mathrm{Br}^{-}$and $\mathrm{Sr}^{2+}$ as well as distinct isotopic content compared to the local groundwater. This distinct nature indicates that the saline springs do not belong to the groundwater system of the present-day hydrological cycle, but show close resemblance with palaeomarine sources.

The spring sites were about $30 \mathrm{~km}$ from the Rann of Kutch (towards north) and about $100 \mathrm{~km}$ from the Gulf of Kutch (towards south), suggesting the absence of any present-day seawater mixing (Figure $1 c$ ). The source of saline springs could be entrapped seawater or groundwater having long interaction with marine sediments. The ionic ratios of both the spring samples show similar values and are comparable to seawater ${ }^{10}$ as compared to 

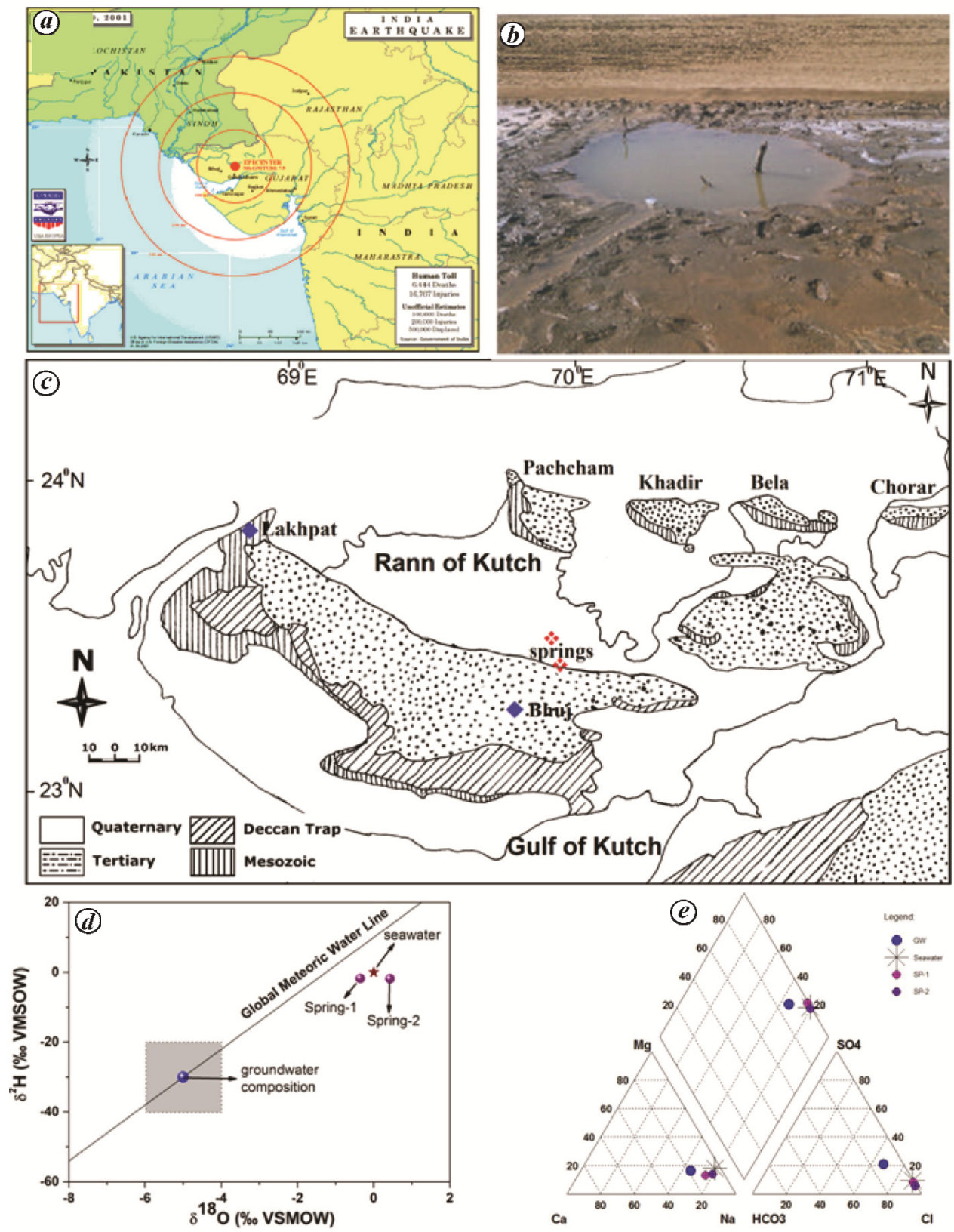

Figure 1. $\boldsymbol{a}$, Epicentre of the earthquake ${ }^{5} . \boldsymbol{b}$, Springs that emerged after the event ${ }^{5} . \boldsymbol{c}$, Location of the springs. $\boldsymbol{d}$, Isotopic identification of spring water source and groundwaters of present day, the shaded portion indicates the extent of isotopic variation. $\boldsymbol{e}$, Piper's trilinear plot of major ion data of springs (shown by triangles), local groundwater (shown by circle) and seawater (shown by star).

local groundwaters ${ }^{11}$ (Table 2). The $\mathrm{Na}^{+} / \mathrm{Cl}^{-}$ratio clearly indicates the marine input to these springs; similarly, $\mathrm{SO}_{4}^{2-} / \mathrm{Cl}^{-}, \mathrm{B} / \mathrm{Cl}^{-}$also signify marine component. Other ratios $\left(\mathrm{Ca}^{2+} / \mathrm{Cl}^{-}, \mathrm{Mg}^{2+} / \mathrm{Cl}^{-}, \mathrm{Sr}^{2+} / \mathrm{Cl}^{-}, \quad \mathrm{HCO}_{3}^{-} / \mathrm{Cl}^{-}\right.$and $\mathrm{K}^{+} / \mathrm{Cl}^{-}$) show some altered signatures, which can be attributed to water-rock interaction. Very high $\mathrm{Li}^{+} / \mathrm{Cl}^{-}$and $\mathrm{Sr}^{2+} / \mathrm{Cl}^{-}$ratios compared to seawater clearly suggest long residence time of saline springs. These spring samples are also characterized by $\mathrm{Mg}^{2+} /\left(\mathrm{Mg}^{2+}+\mathrm{Ca}^{2+}\right)>0.5$ and $\mathrm{Cl}^{-} /$ (sum of anions) $>0.8$, which is an indication of contribution of seawater, evaporate or brine ${ }^{7}$. The molar $\mathrm{Sr}^{2+} / \mathrm{Ca}^{2+}$ ratio of these waters is $\sim 0.02$, which is again an indica- tion of early digenetic marine environment ${ }^{12}$. Many studies have employed characteristic ionic ratios such as the above to infer the saline sources and associated geochemical processes ${ }^{13-16}$. The overall chemical nature of these springs along with the local groundwater average chemical composition and standard seawater composition is shown in Figure $1 e$ Piper's trilinear plot.

In order to differentiate the source of salinity in these springs, whether entrapped seawater or salt dissolution, stable isotopic tracers were employed. The meteoric water as a source to these springs was ruled out from the isotopic signature since the spring samples do not fall on 
the Global Meteoric Water Line. The isotopic composition of spring waters matches with that of seawater, whereas the local groundwater shows a distinct and depleted signature (Figure $1 d$ ).

Previous studies on seawater intrusion in this region have reported a major sea transgression in the Middle Miocene (11.61-15.97 Ma) during which the sea transgressed and crossed over to Radhanpur eastward joining Cambay basin ${ }^{17}$. Pleistocene transgression followed by withdrawal of the sea in the Late Pleistocene $(11,700$ 126,000 a) was reported by Pande and Guha ${ }^{18}$. It was hypothesized that this transgression brought a flux of marine elements in the sea of the Rann of Kutch overlying Pleistocene sediments. Marine transgression also took place during Middle Holocene (4200-8330 a) around 7000 yrs BP and covered the entire Rann of Kutch connecting with the Gulf of Kutch and Gulf of Cambay ${ }^{18,19}$.

Table 1. Chemical and isotopic content of saline springs

\begin{tabular}{|c|c|c|}
\hline & Spring-1 & Spring-2 \\
\hline Location & Lodai (Khangarpar) & Lodai (Dharampar) \\
\hline Temperature $\left({ }^{\circ} \mathrm{C}\right)$ & 31.2 & 31.8 \\
\hline $\mathrm{pH}$ & 6.68 & 7.39 \\
\hline $\mathrm{EC}(\mathrm{mS} / \mathrm{cm})$ & 109 & 101 \\
\hline $\mathrm{F}^{-}(\mathrm{mg} / \mathrm{l})$ & 4.1 & 3 \\
\hline $\mathrm{Cl}^{-}(\mathrm{mg} / \mathrm{l})$ & 38,628 & 39,500 \\
\hline $\mathrm{SO}_{4}^{2-} \quad(\mathrm{mg} / \mathrm{l})$ & 4,648 & 3,200 \\
\hline $\mathrm{NO}_{3}^{-}(\mathrm{mg} / \mathrm{l})$ & 41 & 86 \\
\hline $\mathrm{HCO}_{3}^{-}(\mathrm{mg} / \mathrm{l})$ & 399 & 550 \\
\hline $\mathrm{Li}^{+}(\mathrm{mg} / \mathrm{l})$ & 12 & 10 \\
\hline $\mathrm{Na}^{+}(\mathrm{mg} / 1)$ & 19,250 & 21,750 \\
\hline $\mathrm{K}^{+}(\mathrm{mg} / \mathrm{l})$ & 548 & 350 \\
\hline $\mathrm{Mg}^{2+}(\mathrm{mg} / \mathrm{l})$ & 1,750 & 2,003 \\
\hline $\mathrm{Ca}^{2+}(\mathrm{mg} / \mathrm{l})$ & 2,521 & 1,621 \\
\hline $\mathrm{Sr}^{2+}(\mathrm{mg} / 1)$ & 31.7 & 34.3 \\
\hline $\mathrm{Br}^{-}(\mathrm{mg} / \mathrm{l})$ & 48 & 99 \\
\hline $\mathrm{B}(\mathrm{mg} / \mathrm{l})$ & 4.3 & 7.5 \\
\hline$\delta^{18} \mathrm{O}(\%)$ & -1.85 & 0.43 \\
\hline$\delta^{2} \mathrm{H}(\%)$ & -1.73 & -0.35 \\
\hline
\end{tabular}

Table 2. Ionic ratio of saline springs, average groundwater $(\mathrm{GW})$ and seawater

\begin{tabular}{lllll}
\hline Ionic ratio (wt/wt) & Spring-1 & Spring-2 & Average GW* & Seawater* \\
\hline $\mathrm{Na}^{+} / \mathrm{Cl}^{-}$ & 0.50 & 0.55 & 0.67 & 0.55 \\
$\mathrm{Mg}^{2+} / \mathrm{Cl}^{-}$ & 0.05 & 0.05 & 0.09 & 0.07 \\
$\mathrm{Ca}^{2+} / \mathrm{Cl}^{-}$ & 0.065 & 0.041 & 0.166 & 0.021 \\
$\mathrm{~K}^{+} / \mathrm{Cl}^{-}$ & 0.014 & 0.009 & 0.012 & 0.020 \\
$\mathrm{Li}^{+} / \mathrm{Cl}^{-}$ & 0.00031 & 0.00025 & 0.00014 & 0.00001 \\
$\mathrm{Sr}^{2+} / \mathrm{Cl}^{-}$ & 0.00082 & 0.00087 & 0.00496 & 0.00039 \\
$\mathrm{~B} / \mathrm{Cl}^{-}$ & 0.00011 & 0.00019 & 0.00110 & 0.00023 \\
$\mathrm{HCO}_{3}^{-} / \mathrm{Cl}^{-}$ & 0.0103 & 0.0139 & 0.3043 & 0.0073 \\
$\mathrm{Br}^{-} / \mathrm{Cl}^{-}$ & 0.0012 & 0.0025 & 0.0052 & 0.0034 \\
$\mathrm{SO}_{4}^{2-} / \mathrm{Cl}^{-}$ & 0.12 & 0.08 & 0.42 & 0.14 \\
\hline
\end{tabular}

* Seawater data taken from Brian et al. ${ }^{10}$ and average GW values taken from Keesari et al. ${ }^{11}$.
Gupta et $a .^{20}$ have dated some of the springs that emerged due to the earthquake event using helium dating technique and found that the spring water was about 90,000 years old. Their work was carried out four and a half months after the event took place. A considerable decrease in the spring discharges was noticed by then, and it was also proposed that deep aquifer water is injected through the overlying shallow aquifer system, acquiring in the process variable proportion of shallow groundwater by mixing in different vents. These authors also stated that this might have resulted in underestimation of the estimated ages of the springs and postulated that the highest estimate of the age is likely to be closer to the real age of the deep source ${ }^{20}$. The spring waters collected by them showed electrical conductivity (EC) of $8700 \mu \mathrm{S} / \mathrm{cm}$ (at Nirveri, BSF post). Many researchers have employed binary mixing models to arrive at a more representative age for the groundwater ${ }^{21-25}$. In the present case, the spring waters were collected in about three weeks after the event, and relatively high discharge and high EC clearly indicated that the spring discharges are mostly from deep-seated sources with little mixing from fresh and modern groundwater. Considering a two endmembers linear mixing model with fresh groundwater of the study area as one end-member (EC $745 \mu \mathrm{S} / \mathrm{cm}$; from Keesari et $\left.a l .{ }^{11}\right)$ and saline spring (spring-1 (Sp-1) or spring-2 (Sp-2)) (Table 1) as the other end-member, we found that the spring water collected by Gupta et al. ${ }^{20}$ (EC $8700 \mu \mathrm{S} / \mathrm{cm}$ ) would have only $7.4 \%$ of the saline component. Similarly, the apparent ages of Sp-1 and Sp-2 were determined using the equation

$$
A_{\mathrm{sp}}=\frac{A_{\text {mix }}-\left(1-f_{\mathrm{sp}}\right) A_{\mathrm{gw}}}{f_{\mathrm{sp}}},
$$

where $A_{\mathrm{sp}}$ is the age of the saline spring ( $\mathrm{Sp}-1$ or $\mathrm{Sp}-2$ ), $A_{\text {mix }}$ the He age estimate of the spring after four and a half months (by Gupta et $a l^{20}{ }^{20}$, $f_{\text {sp }}$ the fraction of saline spring water and $A_{\mathrm{gw}}$ is the age of modern groundwater, which is normally considered as within 50 years based on the presence of environmental tritium ${ }^{21,22}$.

According to eq. (3), the saline springs Sp-1 and Sp-2 were found to be 9.6 and 8.9 million years old respectively. Considering the uncertainties in the estimated age by Gupta et al..$^{20}$, and limitation in the approximation of a simple binary mixing adopted in the present study, it can only be suggested that the spring waters might correspond to Miocene and hence their source could be entrapped seawater that transgressed during Middle Miocene $^{17}$. Many palaeontological studies carried out in this region also refer to the Miocene age for excavated fossils $^{1-4}$.

1. https://www.thebetterindia.com/149201/news-indian-dinosaursvaishali-shroff-book/ 
2. https://www.hindustantimes.com/india-news/science-or-sci-fi-the-ignorance-about-dinosaurs-in-india/story-Xz8vEkuJuRzQHfhnQq4FNM. $\underline{\mathrm{html}}$

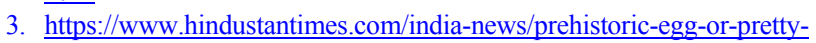
tool-protecting-dinosaur-fossils-in-india/story-XTugah1PglfB6QrEZRMruK.html

4. http://www.sciencemag.org/news/2018/04/india-s-paleontologists-fightdestruction-its-fossil-riches

5. Rajendran, K., Rajendran, C. P., Thakkar, M. and Tuttle, M. P., The 2001 Kutch (Bhuj) earthquake: coseismic surface features and their significance. Curr. Sci., 2001, 80, 1397-1405.

6. EERI, Earthquake Engineering Research Institute Special Earthquake Report, Preliminary observation on the origin and effects of the Jan 26, 2001-Bhuj (Gujarat, India) earthquake. EERI, 2001, pp. 1-16; https://www.istructe.org/downloads/resources-centre/ technical-topic-area/eefit/eefit-reports/bhuj-india.pdf

7. Hounslow, A. W., Water Quality Data Analysis and Interpretation, CRC Press, Florida, USA, 1995.

8. Keesari, T., Shivanna, K. and Jalihal, A. A., Isotope hydrochemical approach to understand fluoride release into groundwaters of Ilkal area, Bagalkot district, Karnataka, India. Hydrogeol. J., 2007, 15, 589-598.

9. Coplen, T. B., New guidelines for reporting stable hydrogen, carbon and oxygen isotope-ratio data. Geochim. Cosmochim. Acta, 1996, 60, 3359-3360.

10. Brian, H., Perkins, E. H. and Gunter, W. D., Introduction to Ground Water Geochemistry, Geoscience Publishing Ltd, Canada, 1999.

11. Keesari, T., Kulkarni, U. P., Deodhar, A., Ramanjaneyulu, P. S., Sanjukta, A. K. and Kumar, U. S., Geochemical characterization of groundwater from an arid region in India. Environ. Earth Sci., 2014, 71(11), 4869-4888.

12. Kinsman, D. J. J., Interpretation of $\mathrm{Sr}^{2+}$ concentrations in carbonate minerals and rocks. J. Sediment. Petrol., 1969, 39, 486508 .

13. Fass, T., Cook, P. G., Stieglitz, T. and Herczeg, A. L., Development of saline groundwater through transpiration of seawater. Ground Water, 2007, 45, 703-710.

14. Warner, N. R. et al., Geochemical evidence for possible natural migration of Marcellus Formation brine to shallow aquifers in Pennsylvania. Proc. Natl. Acad. Sci. USA, 2012, 109(30), 1196111966.

15. Kim, Y. et al., Hydrogeochemical and isotopic evidence of groundwater salinization in a coastal aquifer: a case study in Jeju volcanic island, Korea. J. Hydrol., 2003, 270, 282-294.

16. Mercado, A., The use of hydrogeochemical patterns in carbonate sand and sandstone aquifers to indentify intrusion and flushing of saline water. Groundwater, 1985, 23(5), 635-645.

17. Merh, S. S., Geology of Gujarat, Geological Survey of India, 1995.

18. Pande, J. and Guha, D. K., Termination of last Neogene transgression and some Quaternary shoreline changes in Gujarat. 1st National Seminar on Quat. Envi. Papers (ed. Merh, S. S.), Hindustan Pub Co., Delhi, 1982, pp. 396-412.

19. Merh, S. S. and Chamyal, L. S., The Quaternary sediments in Gujarat. Curr. Sci., 1993, 64, 823-827.

20. Gupta, S. K., Bhandari, N., Thakkar, P. S. and Rengarajan, R., On the origin of the artesian groundwater and escaping gas at Narveri after the 2001 Bhuj earthquake. Curr. Sci., 2002, 82, 463-468.

21. Clark, I. and Fritz, P., Environmental Isotopes in Hydrogeology, Lewis Publ., Boca Raton, FL, USA, 1997, p. 328.

22. Solomon, D. K., Genereux, D. P., Plummer, L. N. and Busenberg, E., Testing mixing models of old and young groundwater in a tropical lowland rainforest with environmental tracers. Water Resour. Res., 2010, 46, W04518; doi:10.1029/2009WR008341.

23. Cook, P. G. and Böhlke, J. K., Determining timescales for groundwater flow and solute transport. In Environmental Tracers in Subsurface Hydrology (eds Cook, P. G. and Herczeg, A.), Kluwer, Boston, Mass., USA, 2000, pp. 1-30.

24. Schlosser, P., Stute, M., Doff, H., Sonntag, C. and Munnich, K. O., Tritium $/{ }^{3} \mathrm{He}$ dating of shallow groundwater. Earth Planet. Sci. Lett., 1988, 89, 352-363; doi:10.1016/0012-821X(88)90122-7.

25. Cook, P. G., Plummer, L. N., Solomon, D. K., Busenberg, E. and Han, L. F., Effects and processes that can modify apparent CFC age. In Use of Chlorofluorocarbons in Hydrology: A Guidebook, International Atomic Energy Agency, Vienna, Austria, 2006, pp. 31-58.

ACKNOWLEDGEMENTS. We thank the staff members of Isotope Hydrology Section, Bhabha Atomic Research Centre, Mumbai and National Dairy Development Board, Gujarat for help during sampling.

Received 23 July 2018; revised accepted 10 February 2019

doi: $10.18520 / \mathrm{cs} / \mathrm{v} 116 / \mathrm{i} 8 / 1407-1410$

\section{Origin and distribution of shallow gas-charged sediment on the inner continental shelf of central west coast of India}

\author{
K. M. Dubey ${ }^{1,2}$ and A. K. Chaubey ${ }^{3, *}$ \\ ${ }^{1}$ CSIR-National Institute of Oceanography, Dona-Paula, \\ Goa 403 004, India \\ ${ }^{2}$ Department of Marine Sciences, Goa University, \\ Taleigao Plateau, Goa 403 206, India \\ ${ }^{3}$ CSIR-National Institute of Oceanography, Regional Centre, \\ Andheri (W), Mumbai 400 053, India
}

High-resolution shallow seismic investigations on inner continental shelf of Goa have been carried out to map gas-charged sediment zones and investigate origin of trapped gas. Analyses of data reveal that the gas is trapped by different stratigraphic layers and is distributed in two zones. Zone- 1 is restricted up to $\sim 30 \mathrm{~m}$ water depth and in the southern part of the study area. In this zone, gas is confined within the Holocene layers above the Holocene maximum Hooding surface (MFS). Whereas, zone-2 is comprised of several isolated gas-charged patches which are distributed in the entire study area mostly between $\sim 20 \mathrm{~m}$ and $\sim 45 \mathrm{~m}$ water depth. In this zone, gas is confined below Holocene-MFS in incised river bed or a layer just below MFS or both. Gas-charged sediment in zone-1 is formed due to degradation of organic material which is predominantly early Holocene mangrove derived, whereas, zone-2 it is formed due to degradation of

*For correspondence. (e-mail: chaubey@nio.org) 